OPTIMUM. STUDIA EKONOMICZNE NR 6 (72) 2014

\author{
Joanna JUSZCZUK ${ }^{1}$
}

\title{
INTELIGENTNY ROZWÓJ POLSKI I UNII EUROPEJSKIEJ
}

\begin{abstract}
Streszczenie
Inteligentny rozwój Polski i Unii Europejskiej to strategia Zjednoczonych Państw Europy polegająca na rozwoju gospodarki opartej na wiedzy i innowacji. Stanowi on swoistą, długofalową wizję społecznej gospodarki rynkowej przyjętą w 2010 roku przez Unię Europejską w celu wyjścia z kryzysu gospodarczego.

Opracowana strategia „Europa 2020”, jak również Program Operacyjny Inteligentny Rozwój mają zapewnić państwom członkowskim Unii Europejskiej wkroczenie na drogę zrównoważonego wzrostu, który w przyszłości zapewni dobrobyt i postęp społeczny.

W tych wspólnych działaniach Unii Europejskiej najistotniejsze są procesy rozwojowe oparte na: wiedzy, innowacji, inwestycjach i właściwie zarządzanych finansach. Po kryzysie przywódcy Europy 2008 roku dostrzegli, że powstaje nowy paradygmat technologiczny. Tworzy się nowe społeczeństwo informacyjne i społeczeństwo wiedzy. Z tego też względu w państwach członkowskich Unii obowiazkowo muszą być wprowadzone i realizowane prawne zasady prowadzenia polityki rozwoju. Każda z polityk narodowych musi uwzględniać trzy strategiczne priorytety w zakresie rozwoju, tj.: wzrost inteligentny, wzrost zrównoważony i wzrost sprzyjający włączeniu społecznemu. Aktualnie postęp kulturalno-cywilizacyjny wręcz wymusza na państwach przyjęcie w swoich strategiach krajowych i polityce rozwoju pięciu kluczowych celów w przedmiocie: zatrudnienia, inwestycji, emisji gazów cieplarnianych, nauki i kształcenia oraz wykluczenia i ubóstwa.

W Polsce zostały przyjęte i są wdrażane krajowe programy reform wyznaczające sposoby realizacji priorytetów i celów strategii „Europa 2020”. Godne uwagi jest to, że realizacje priorytetów i celów krajowych wspiera Komisja Europejska, dążąc do tego, aby rozwój zrównoważony, wspierając gospodarkę krajowa, efektywniej korzystał z zasobów i był bardziej przyjazny środowisku dla dobra przyszłych pokoleń.
\end{abstract}

Słowa kluczowe: cywilizacja, inteligentny rozwój, procesy rozwojowe, wiedza, innowacyjność, inwestycje, finanse, polityka rozwoju, strategia rozwoju

\section{SMART DEVELOPMENT OF POLISH AND THE EUROPEAN UNION}

\section{Summary}

Smart development of Polish and the European Union is a strategy of the United States of Europe involving the development of an economy based on knowledge and innovation. It is peculiar, long-term vision of the social market economy adopted in 2010 by the European Union to exit from the economic crisis.

Developed strategy, „Europe 2020” as well as the Operational Programme Development of Intelligent shall provide the Member States of the European Union encroachment on the path of sustainable growth, which in the future will ensure prosperity and social progress.

\footnotetext{
${ }^{1}$ Mgr Joanna Juszczuk - Wydział Ekonomii i Zarządzania, Uniwersytet w Białymstoku; e-mail: juszczuk.joanna@gmail.com.
} 
In these joint activities of the European Union's most important developmental processes are based on knowledge, innovation, investment, and well-managed finances. The leaders of Europe after the crisis 2008 years have recognized that a new technological paradigm. Creates a new information society and knowledge society. Therefore, in the Member States of the Union must necessarily be introduced and implemented the legal principles of development policy. Each national policies must take account of three strategic priorities for development ie smart growth, sustainable growth and growth conducive to social exclusion. At present, the progress of culture and civilization simply forces the adoption of their national strategies and development policies to achieve five key objectives concerning employment, investments, greenhouse gas emissions, science and education, and poverty and social exclusion.

In Poland, have been adopted and are being implemented in the national reform programs defining the ways of the priorities and objectives of the strategy, „Europe 2020”. Worth emphasizing is that the priorities and objectives of the national supports the European Commission with a view to the sustainable development to support the domestic economy more efficient use of resources and a more friendly environment for future generations.

Key words: civilization, smart growth, development processes, knowledge, innovation, investment, finance, development policy, strategy development

\section{Wstęp}

W obecnym, burzliwym, dążącym do globalizacji świecie zachodzą zjawiska częściowo niezrozumiałe dla większości ludzi przyzwyczajonych do utartych i starych schematów postępowania. Dokonujący się w bardzo szybkim tempie postęp technologiczny i cywilizacyjny pozostawia na boku społeczeństwo postindustrialne, które we współczesnym postępie widzi zagrożenie dla swego bytu. Również w sferach decyzyjnych powstają watpliwości co do możliwości i zakresu wykorzystania nowoczesnych technologii informatycznych i umiejętnego wykorzystania wiedzy technicznej przez całe społeczeństwo.

W kręgach naukowych zauważa się, że nie nadąża się z teoretycznym opracowaniem koncepcji gospodarowania wszystkimi zasobami: ziemi, kapitału, pracy i wiedzy w taki sposób, aby faktycznie w świecie następował zrównoważony rozwój gospodarki oparty na wiedzy dla dobra obecnych i przyszłych pokoleń.

Wszystko to stwarza potencjalne zagrożenia dla każdej gospodarki państwa, które nie potrafi umiejętnie kierować procesami rozwojowymi. W drugiej dekadzie XXI wieku miało miejsce przyśpieszenie procesu konwergencji Polski z krajami Unii Europejskiej. Ograniczenie dystansu rozwojowego pomiędzy Polską a wysoko rozwiniętymi państwami Unii Europejskiej nastapiło dzięki umiejętnemu prowadzeniu polityki rozwoju stymulującej wzrost gospodarczy oparty na: wiedzy, innowacyjności i konkurencyjności gospodarki kraju i regionu. $Z$ tego też względu wszystkie procesy rozwojowe powinny być oparte na: wiedzy, innowacyjności, inwestycjach i umiejętnym zarządzaniu finansami.

Celem pracy jest ukazanie procesów rozwojowych opartych na wiedzy, która jest źródłem stanowienia racjonalnych zasad polityki rozwoju każdego kraju, jak również zaprezentowanie i ocena strategii rozwoju na podstawie Programu Operacyjnego Inteligentny Rozwój. 


\section{Procesy rozwojowe - wiedza i innowacyjność}

Tempo zmian ekonomicznych we współczesnym świecie zrodziło uzasadnione obawy społeczeństw i obywateli Ziemi co do przyszłości gospodarki światowej. Obecnie jesteśmy świadkami wielu głębokich i gwałtownych przemian w przemyśle komputerowym i telekomunikacyjnym. Długotrwały wzrost gospodarczy oraz postęp naukowotechniczny przyczynily się do powstawania organizacji nowego typu zarówno między państwami, jak i przedsiębiorstwami. Postępująca globalizacja w połączeniu z ekonomiczną niepewnością zmusiły państwa, przedsiębiorstwa i organizacje międzynarodowe do ściślejszej wspólpracy. Rozwój technologii spowodował istotne zmiany także w zakresie organizacji i wykonywania pracy. Liczne odkrycia naukowe i innowacje technologiczne ostatnich dekad złożyły się na powstanie nowego paradygmatu technologicznego. Jego specyfika polega na tym, że w procesie tworzenia innowacji w równej mierze surowcem, jak i produktem końcowym jest informacja.

Powstaje społeczeństwo informacyjne i społeczeństwo wiedzy. Symptomem powstania społeczeństwa informacyjnego i społeczeństwa wiedzy może być niezwykle rozwinięty informacyjny wymiar strategii zrównoważonego rozwoju i towarzyszącej mu gospodarki opartej na wiedzy [Czaja, 2009, s. 203, 207].

Każda gospodarka zawsze była i jest nieodłącznie związana z wiedza, która ma charakter statyczny. Współczesna gospodarkę cechują szybkie zmiany wiedzy. Mówi się o niej jako gospodarce napędzanej wiedza. W literaturze przedmiotu stwierdza się, że siła napędowa zmian powinna być, jak na przestrzeni dziejów, edukacja, nauka i technika, z tym że tradycyjna edukacja nie jest wystarczająca. Bowiem dla zrównoważonego i trwałego rozwoju są potrzebne nowe elementy rozszerzające formułę wiedzy. Tak więc czynnikiem sprawczym procesów rozwojowych w skali mikro i makro powinno być stosowanie nowych elementów wiedzy świadczaccych o jej innowacyjności. Należy podkreślić, że współczesne innowacje cechuje zdolność do samokreacji popytu, czyli poszukiwania doskonalszych form zaspokajania istniejącej potrzeby. Złożoność problemów zrównoważonego i trwałego rozwoju w skali globalnej wymaga transdyscyplinarnej nauki, pozytywnie ukierunkowanej na rozwój całości.

W doktrynie podkreśla się, że szybkie zmiany wiedzy niezwykle utrudniają aktualizowanie posiadanej wiedzy, nie wspominając już o ustaleniu, jaka wiedza będzie potrzebna w przyszłości. Przy tego rodzaju założeniu jedna kwestia jest pewna, że szybsze uczenie się może okazać się jedyną i trwała przewagą konkurencyjną. Potrzeba zrozumienia tego, jak społeczeństwa $\mathrm{i}$ ich organizacje powinny się uczyć i przyśpieszać ten proces jest dziś pilniejsza niż kiedykolwiek. Stare, dobre czasy minęły bezpowrotnie w aktualnym świecie, który staje się coraz bardziej dynamiczny, niesterowalny i nieprzewidywalny. Chociaż między naukowcami, jak i decydentami nie ma zgodności co do tego, jak będzie wyglądać gospodarka jutra, to należy przypuszczać, iż wiedza i informacja będą w niej stanowić główne źródło wartości ekonomicznej. Dlatego też należy w chwili obecnej przywiązywać ogromna wagę do uczenia się.

W literaturze przedmiotu pojawily się opinie podkreślające okoliczność, że ludžie, któryy osiagneli nysoki poziom mistryostwa osobistego, nigdy nie przestaja sie ucsyć. Sa śniadomi swoich niedoskonatości (niewiedsyy, niekompetencji), ale takize kierunków dalszego rozwoju osobistego 
[Powichrowska, 2011, s. 82].

Progresywne uczenie się stanowi więc podstawowy czynnik sprawczy procesów rozwojowych. Niebagatelny wpływ na nasze życie i na rozwój gospodarki ma również postęp techniczny, z czego większość ludzi nie zdaje sobie sprawy. Wielu autorów publikacji z dziedziny zarządzania twierdzi, że o przewadze jednej organizacji (państwa, przedsiębiorstwa) nad drugą decyduja trzy czynniki: mądre pozycjonowanie, zasoby i obsesja wiedzy, czyli koncentracja na pomnażaniu wiedzy i ciagłym rozwijaniu umiejętności.

Wiedza stanowi źródło trwałej przewagi konkurencyjnej, pod warunkiem że w przeciwieństwie do innych zasobów rozrasta się w wyniku użytkowania. $Z$ pomysłu rodzą się kolejne pomysły, a dzieląc się wiedzą nie tracimy jej, natomiast wzbogacamy innych. Pomnażanie wiedzy oznacza tchnięcie nowego ducha w człowieka (lub w firmę). Największy przyrost wiedzy następuje w efekcie pracy grupowej. Wiedza zespołowa nie jest sumą wiedzy poszczególnych jej członków. Jednak stanowi ogromny potencjał pozwalający na kreowanie nowych pomysłów, idei, koncepcji. Wymiana myśli, doświadczeń i przemieszczanie się wiedzy jest czynnikiem prowadzącym do zmian jakościowych, zachodzących zarówno w poszczególnych krajach, jak i w gospodarce światowej.

Zachodzi dynamiczne przemieszczanie się technologii i działalności badawczo-rozwojowej w skali światowej, czego efektem jest upowszechnienie nowych metod produkcji i rozwiązań technologicznych.

Wiedza techniczna, również określana mianem technologii lub po prostu wiedzy, jest rozumiana najczęściej jako: zasób informacji $i$ sposobów stosowanych w celu zmian w środowisku materiahnym i/lub spotecznym, m.in. priy nytwarzaniu towaru i swiadczeniu uslug, a takize prayy realizacji innego typu dziatalności gospodarczej [Bożyk, Misala, Puławski, 2002, s. 170].

Istotnym czynnikiem sprawczym procesów rozwojowych jest równocześnie wiedza techniczna, która rozwija się w procesie ciagłego uczenia się. Należy podkreślić, że postęp techniczny w aspekcie ekonomicznym ma miejsce, gdy pojawiają się nowe metody wytwarzania danego produktu, których skutkiem jest wzrost efektywności czynników produkcji, bądź też pojawiają się jakościowo lepsze lub nowe produkty.

W tych realiach ekonomicznych wiedza techniczna jest utożsamiana z: technologia, wiedzą naukowo-techniczną i wiedzą organizacyjno-techniczną. W literaturze przedmiotu nie ma jednolitego stanowiska na temat jednoznacznego zdefiniowania, czym jest technologia.

Tomasz Rynarzewski wskazuje, że technologia może być rozumiana w węższym znaczeniu jako informacja techniczna zawarta w patentach lub dokumentacji technicznej, która odnosi się do konkretnego produktu lub procesu produkcyjnego [Rynarzewski, 2005, s. 25]. Jest to wiedza szczegółowa, skonkretyzowana i dająca się zastosować w określonym cyklu produkcyjnym.

W szerszym rozumieniu technologia to cały system produkcyjny, łącznie ze sposobem organizacji produkcji. Rozwój nowych technologii, środków komunikacji i transportu sprzyja globalizacji, która dla konsumentów oznacza poszerzenie wyboru dóbr $i$ usług. Jest to proces pozytywny, ponieważ przedsiębiorstwa, aby nie wypaść z gry, muszą umieć robić nowe rzeczy dobrze i w dodatku szybko. Ponadto skuteczność wy- 
korzystania technologii zależy od szybkości jej przemieszczania. Jednak należy zauważyć, że rozwój nauki i techniki na świecie nie przebiega bezkonfliktowo. Już autorzy obu raportów Klubu Rzymskiego sygnalizowali niebezpieczeństwo wyczerpywania się zasobów energetycznych i surowcowych oraz wskazywali na polityczny i społeczny egoizm społeczeństw postindustrialnych. Co więcej, pojawiają się wśród naukowców głosy o wizjach katastroficznych i być może utopijnych.

Dariusz Waldziński, utożsamiając kryzys gospodarczy z kryzysem kultury, konstatuje następująco: można oczymiście stwierdzić, ze skoro zmienia sie swiat, to zmienia sie również. gospodarka $i$ kultura $i$ nic na to nie można poradzić. Trudno jednak zaakeceptowac taki punkt widze-

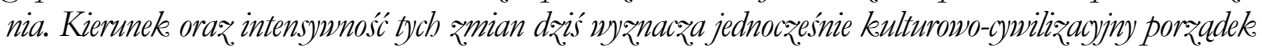

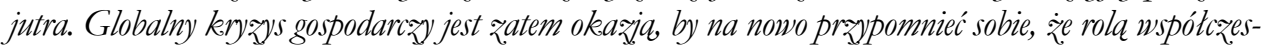
nych ekonomistón - teoretyków i praktykéw sa dziatania kulturotwórcze. Bez nich wizja gospodarki opartej na wiedsy zmieni sie w rzecryynistość wszechogarniajacego chaosu. W konsekwencii ostabiona lub wrecz. zdegradowana kultura ustapi miejsca coraz silniejszej naturze, co prayscyyni sie do tego, że o porzqdku w zaspokajaniu potrzeb ludrkich decydować bedrie walka i siła. Inna ewentualnościa bęrzie powstanie jakiejs nowej utopii, która doprowadri do powstania kolejnych totalitarnych systemów. Takie rozwiazania ludzkooś́ już przesiywata w XX wieku $i$ oby nie by to ku temu kolejnych okazji [Waldziński, 2009, s. 106-107].

Te przytoczone i inne ostrzeżenia stały się między innymi podstawą budowy pozytywnych prognoz globalnych rozwoju gospodarki światowej. Globalna prognoza uwzględnia pięć głównych celów polityki naukowej i technologicznej świata, a są to:

1. Podniesienie poziomu życia, rozwój rolnictwa, rozwój urbanizacji, modernizacja transportu, działania proekologiczne i na rzecz wzrostu bezpieczeństwa;

2. Rozwój hardware i software oraz wykorzystanie upowszechniania informacji w życiu społeczno-ekonomicznym;

3. Wzrost wydajności w sektorze rolnym - zarówno w produkcji, jak i w przetwórstwie;

4. Rozwój profilaktyki i terapeutyki jako poprawy funkcjonowania środowiska człowieka;

5. Rozwój wykorzystania: mórz, źródeł energii i bogactw naturalnych [Rymarczyk, 2010, s.143].

Skuteczność prognoz globalnych zależy od koordynacji działań wszystkich państw i organizacji. Jest to globalne wyzwanie dla świata, w którym rozwój nauki i techniki stanowi podstawowy element.

\section{Zasady prowadzenia polityki rozwoju}

Prowadzenie polityki rozwoju społeczno-gospodarczego należy do obowiązków organów państwa. Państwo polskie, realizując konstytucyjną zasadę zrównoważonego rozwoju zawartą w art. 5 Konstytucji oraz kierując się nowymi unijnymi rozwiązaniami w celu osiagnięcia wyższej dynamiki rozwoju cywilizacyjnego Polski, uchwaliło Ustawe o zasadach prowadzenia politykei rozwoju [Ustawa z dnia 06.12.2006 roku o zasadach prowadzenia polityki rozwoju, 2009]. 
Podstawowym celem tej ustawy jest stworzenie ram prawnych, które porządkuja w Polsce sposób prowadzenia polityki rozwoju społeczno-gospodarczego, czyli polityki spójności. Ustawa o zasadach prowadzenia polityki ro zuoju po raz pierwszy wprowadziła definicje pojęcia polityki rozwoju, przyjmując konstrukcję tej definicji przez wyszczególnienie, tworząc katalog otwarty dziedzin, które składają się na politykę rozwoju. Zgodnie z artykułem 2. ustawy: pržez polityke rozwoju rozumie sie zespót wrajemnie poniqzanych działań podejmowanych $i$ realizowanych $w$ celu zapewnienia trwatego $i$ zrónnoważonego rozwoju kraju, spójności społeczno-gospodarczej, regionalnej i przestrzennej, podnoszenia konkurencyjności gospodarki oraz tworzenia nowych miejsc pracy w skali krajowej, regionalnej lub lokalnej [Ustawa z. dnia 06.12.2006 roku o zasadach prowadzenia polityki ro:woju, 2009].

Do podstawowych dziedzin życia społeczno-gospodarczego ustawa zalicza: ochronę środowiska, ochronę zdrowia, promocję zatrudnienia, rozwój kultury, kulturę fizyczna, sport i turystykę, rozwój miast i obszarów metropolitarnych, rozwój obszarów wiejskich, rozwój nauki i zwiększenie innowacyjności gospodarki, rozwój zachowań prospołecznych, wspólnot lokalnych oraz budowę i umacnianie struktur społeczeństwa obywatelskiego, rozwój zasobów ludzkich, stymulowanie powstawania nowych miejsc pracy, tworzenie i modernizacje infrastruktury społecznej i technicznej, wspieranie i unowocześnianie instytucji państwa, wspieranie rozwoju przedsiębiorczości, wspieranie wzrostu gospodarczego i zwiększanie konkurencyjności gospodarki.

Ponadto ustawa po raz pierwszy kompleksowo reguluje zagadnienia dotyczace mechanizmów związanych z długoterminową strategią rozwoju, wskazuje krąg podmiotów zaangażowanych w ten proces, zwłaszcza wszelkie źródła finansowania polityki rozwoju, a także definiuje zasady prowadzenia polityki strukturalnej i podstawowe dokumenty służące temu celowi. Jednocześnie ustawodawca postanowił, że przepisów ustawy nie stosuje się do programów współfinansowanych z Europejskiego Funduszu Rolnego na rzecz Rozwoju Obszarów Wiejskich i Europejskiego Funduszu Rybackiego [Duszyński, 2007, s. 8].

Wynika to ze specyfiki postępowania w tym zakresie, gdyż są one realizowane na podstawie odrębnych przepisów. W artykule 3. ustawy wskazano podmioty prowadzące politykę rozwoju w Polsce. W skali kraju jest to Rada Ministrów, w skali regionów samorząd województwa, a w skali lokalnej samorząd powiatowy i gminny.

Z uwagi na potrzebę należytej absorpcji środków finansowych z Unii Europejskiej, przeznaczonych do wykorzystania w Polsce w latach 2007-2013, powstała konieczność dostosowania zasad prawnych prowadzenia polityki rozwoju do unijnych zasad polityki strukturalnej. Po pierwsze, zasada, którą można nazwać zasadą prowadzenia polityki rozwoju w oparciu o strategię rozwoju - nazywana jest również zasada programowania. Do strategii rozwoju zalicza się: strategię rozwoju kraju (SRK), strategie sektorowe, strategie rozwoju województw oraz strategie rozwoju lokalnego, w tym strategie rozwoju powiatu oraz strategie rozwoju gmin [Strategia Rozwoju Kraju..., 2006, s. 93].

Po drugie, na podstawie artykułu 6-8 ustawy można sformułować także zasadę polegająca na obowiązku konsultacji wszystkich strategii, programów operacyjnych oraz planów wykonawczych pomiędzy podmiotami opracowującymi te dokumenty a jednostkami samorządu terytorialnego, partnerami społecznymi i gospodarczymi, a tak- 
że Komisją Wspólną Rządu i Samorządu Terytorialnego. Wskazany obowiązek konsultacji realizuje, wyrażona w prawie unijnym, zasadę partnerstwa horyzontalnego, gdyż zakłada współpracę między krajowymi organami szczebla centralnego a organami szczebla samorządowego i innymi podmiotami realizującymi politykę rozwoju. Kolejnym przejawem tej zasady jest funkcjonowanie instytucji Stałej Konferencji Współpracy, która stanowi forum wymiany informacji dotyczących zagadnień regulowanych ustawa, a zwłaszcza w sprawach związanych ze strategia rozwoju województwa oraz regionalnych i krajowych programów operacyjnych.

Ustawodawca nałożył na wojewodów obowiazzek powoływania stałych konferencji. W skład konferencji wchodzą: wojewoda jako przewodniczący, marszałek województwa, przedstawiciele gmin i powiatów z terenu województwa oraz przedstawiciele ministrów, których zakres działania obejmuje sprawy będące przedmiotem konferencji. Z postanowień ustawy można wyprowadzić trzecią zasadę aktualizacji strategii rozwoju kraju (SRK), która powinna następować raz na cztery lata. Zasada ta jest szczególnie wartościowa, ponieważ pozwala reagować na zmiany czy nowe wyzwania często występujące w ramach polityki rozwoju.

Po czwarte, można wskazać na zasadę realizacji polityki strukturalnej, głównie za pomoca programów operacyjnych i regionalnych programów operacyjnych. Nieodłącznym elementem każdego programu operacyjnego jest plan finansowy, zawierający: określenie źródeł finansowania realizacji programu, kwotę środków przeznaczonych na finansowanie realizacji programu i jej podział na poszczególne priorytety. Program operacyjny musi także wyznaczać sposób monitorowania i oceny stopnia osiagania celu głównego i celów szczegółowych.

Instrumenty finansowe odgrywają zasadniczą rolę przy zarządzaniu gospodarka, z tego też względu należałoby postulować, aby z ustawy wyodrębnić zasadę tematycznego ujmowania programów operacyjnych w planach wykonawczych. Warto zauważyć, że ustawodawca w rozdziale piątym Ustawy o zasadach prowadzenia polityki rozwoju skonstruował zasadę koordynacji i odpowiedzialności instytucji zarządzającej za realizację i przygotowanie programu operacyjnego. W przypadku krajowego programu operacyjnego instytucją zarządzająca jest właściwy Minister do spraw Rozwoju Regionalnego, a w odniesieniu do regionalnego programu jest to Zarząd Województwa [Ustawa z. dnia 06.12.2006 roku..., 2009].

Katalog zadań instytucji zarządzającej jest określony w artykule 26 i 35 ustawy. Na wyjątkowa uwagę zasługują zadania związane z przygotowaniem szczegółowego opisu priorytetów programu operacyjnego, zawierane z beneficjentami umów o dofinansowanie projektu czy monitorowanie postępów w realizacji, a także ewaluacja programu operacyjnego oraz stopnia osiagania jego celów.

Godne podkreślenia jest to, że ustawodawca nałożył na Ministra do spraw Rozwoju Regionalnego odpowiedzialność za koordynację w zakresie wykorzystania środków pochodzących ze źródeł zagranicznych, w tym z budżetu Unii Europejskiej, przeznaczonych na dofinansowanie programów operacyjnych.

Po siódme, można wyróżnić również zasadę spójności i kompatybilności programów operacyjnych z przepisami prawa Unii Europejskiej. 


\section{Strategia rozwoju a programy operacyjne}

Inteligentny rozwój oznacza uzyskanie lepszych wyników w dziedzinie:

- edukacji - zachęcanie do nauki, studiów i podnoszenia kwalifikacji;

- badań naukowych, innowacji - stworzenie nowych produktów i usług, które wpłynęłyby na zwiększenie wzrostu gospodarczego i zatrudnienia oraz pomogłyby w rozwiązywaniu problemów społecznych;

- $\quad$ społeczeństwa cyfrowego - wykorzystanie technologii informacyjnych i komunikacyjnych [Dokument elektroniczny, tryb dostępu: http://ec.europa.eu/ europe2020/europe-2020-in-a-nutshell/priorities/smart-growth/index_pl. htm, data wejścia: 20.06.2014].

Rok 2010 pokazał, że kryzys finansowo-gospodarczy zniweczył wyniki wielu lat postępu gospodarczego i społecznego, jak również odsłonił strukturalne słabości europejskiej gospodarki. Świat zmieniał się bardzo szybko, a Europa zaczęła pozostawać w tyle. Jak stwierdził Jose Manuel Barroso, Europa musi wrócić na ścieżkę rozwoju, a następnie na niej pozostać. Podkreślił, że na przykładzie światowych skutków kryzysu finansowego wyraźnie widać, że warunki gospodarcze zmieniają się szybciej niż sytuacja polityczna. Ostatnie lata ujawniły podstawowe realia o problemach, z jakimi boryka się europejska gospodarka. Kryzys był dzwonkiem alarmowym, dzięki któremu Unia Europejska zorientowała się, że jeżeli niczego nie zmieni, to spadnie do drugiej ligi nowego światowego porządku. Dla Unii Europejskiej nadszedł moment prawdy i czas na działania stanowcze i ambitne. Europa musi zatroszczyć się o swoją przyszłość i może odnieść sukces, jeśli będzie działać wspólnie jako Unia. Potrzebuje więc strategii, dzięki której wyjdzie z kryzysu, a jej gospodarka stanie się inteligentna i zrównoważona, a także będzie mogła pochwalić się wysokimi wskaźnikami zatrudnienia i wydajności oraz większą spójnością społeczną. Wszyscy europejscy przywódcy zgodzili się co do tego, że nowe wyzwania są bardzo pilne i wspólnie powinni stawić im czoło. Zaznaczyli oni, że Europa ma: wiele silnych stron, zdolnych pracowników, solidną bazę technologiczną i przemysłową, rynek wewnętrzny i wspólną walutę, które pomogły Europie przetrwać załamanie, jak również wypróbowaną społeczną gospodarkę rynkowa. Wskazywano na konieczność wytyczenia ambitnego programu, a następnie uruchomienia wszystkich wysiłków, aby go zrealizować. Europa bowiem czeka na zmiany i potrzebuje inteligentnego rozwoju. To hasło stało się podstawą opracowania, a później uchwalenia strategii „Europa 2020”.

W opublikowanym 3 marca 2010 roku Komunikacie „Europa 2020 - Strategia na rzecz inteligentnego i zrównoważonego rozwoju sprzyjającego włączeniu społecznemu" została podkreślona potrzeba wspólnego działania państw członkowskich na rzecz wychodzenia z kryzysu oraz wdrażania reform umożliwiających sprostanie wyzwaniom związanym z: globalizacja, starzeniem się społeczeństw czy rosnącą potrzebą racjonalnego wykorzystywania zasobów.

W celu osiagnięcia powyższych założeń zaproponowano trzy podstawowe, wzajemnie wzmacniające się, priorytety:

- $\quad$ wzrost inteligentny (ang. smart growth), czyli rozwój oparty na wiedzy i innowacjach; 
- $\quad$ wzrost zrównoważony (ang. sustainable growth), czyli transformacja w kierunku gospodarki niskoemisyjnej, efektywnie korzystającej z zasobów i konkurencyjnej;

- $\quad$ wzrost sprzyjający włączeniu społecznemu (ang. inclusive growtb), czyli wspieranie gospodarki charakteryzującej się wysokim poziomem zatrudnienia i zapewniającej spójność: gospodarczą, społeczną i terytorialną.

Następnie Rada Europejska na posiedzeniu 17 czerwca 2010 roku uchwaliła „Strategię na rzecz inteligentnego i zrównoważonego rozwoju sprzyjającego włączeniu społecznemu Europa 2020".

Strategia „Europa 2020” jest nowym, długookresowym programem rozwoju społeczno-gospodarczego Unii Europejskiej (UE), który zastąpił realizowaną od 2000 roku, zmodyfikowana pięć lat później, Strategię Lizbońską.

Jest to dokument o znaczeniu fundamentalnym dla rozwoju Unii Europejskiej w ciągu najbliższych lat do 2020 roku. Określa działania, których podjęcie przez państwa członkowskie w sposób skoordynowany przyśpieszy wyjście z obecnego kryzysu i przygotuje europejska gospodarkę do wyzwań przyszłości.

Strategia wyznacza trzy priorytety, których realizacja będzie odbywać się na szczeblu unijnym oraz krajowym. Efektem realizacji priorytetów strategii „Europa 2020” będzie osiagnięcie pięciu współzależnych, nadrzędnych celów zaproponowanych przez Komisję Europejską wszystkim państwom członkowskim. Cele te dotyczą w szczególności:

- osiagnięcia wskaźnika zatrudnienia na poziomie $75 \%$;

- poprawy warunków prowadzenia działalności badawczo-rozwojowej, w tym przeznaczania 3\% PKB Unii Europejskiej na inwestycje w badania i rozwój;

- zmniejszenia emisji gazów cieplarnianych o $20 \% \mathrm{w}$ porównaniu z poziomami z 1990 roku, zwiększenia do 20\% udziału energii odnawialnej w ogólnym zużyciu energii i dążenia do zwiększenia efektywności energetycznej o $20 \%$;

- podniesienia poziomu wykształcenia, zwłaszcza przez zmniejszenie odsetka osób przedwcześnie kończących naukę do poniżej 10\%, a także zwiększenie co najmniej do 40\% odsetek osób w wieku 30-34 lata z wyższym wykształceniem;

- $\quad$ wspierania włączenia społecznego, głównie ograniczanie ubóstwa, mając na celu wydźwignięcie z ubóstwa lub wykluczenia społecznego 20 milionów obywateli [Dokument elektroniczny, tryb dostępu: http://www.mg.gov.pl/Bezpieczen stwo+gospodarcze/Strategia+Europa+2020, data wejścia: 20.06.2014].

Podstawowymi instrumentami realizacji celów strategii „Europa 2020” są opracowywane przez państwa członkowskie Unii Europejskiej Krajowe Programy Reform oraz przygotowane przez Komisję Europejska inicjatywy przewodnie (ang. flagship initiatives), zwane także inicjatywami flagowymi, a realizowane na poziomie: Unii Europejskiej, państw członkowskich, władz regionalnych i lokalnych.

Do wspomnianych inicjatyw przewodnich należa:

- „Unia innowacji” - projekt na rzecz poprawy warunków ramowych i dostępu do finansowania badań $i$ innowacji, tak by innowacyjne pomysły przeradza- 
ły się w nowe produkty i usługi, które z kolei przyczynią się do wzrostu gospodarczego i tworzenia nowych miejsc pracy;

- „Młodzież w drodze” - projekt na rzecz poprawy wyników systemów kształcenia oraz ułatwiania młodzieży wejścia na rynek pracy;

- „Europejska agenda cyfrowa” - projekt na rzecz upowszechnienia szybkiego Internetu i umożliwienia gospodarstwom domowym i przedsiębiorstwom czerpania korzyści z jednolitego rynku cyfrowego;

- „Europa efektywnie korzystająca z zasobów” - projekt na rzecz: uniezależnienia wzrostu gospodarczego od wykorzystania zasobów, przejścia na gospodarkę niskoemisyjna, większego wykorzystania odnawialnych źródeł energii, modernizacji transportu oraz propagowania efektywności energetycznej;

- „Polityka przemysłowa w erze globalizacji” - projekt na rzecz poprawy otoczenia biznesu, szczególnie w odniesieniu do MŚP, a także wspierania rozwoju silnej i zrównoważonej bazy przemysłowej, przygotowanej do konkurowania na rynkach światowych;

- „Program na rzecz nowych umiejętności i zatrudnienia” - projekt na rzecz modernizacji rynków pracy i wzmocnienia pozycji obywateli dzięki rozwojowi kwalifikacji przez całe życie w celu zwiększenia współczynnika aktywności zawodowej i lepszego dopasowania popytu do podaży na rynku pracy, między innymi dzięki mobilności siły roboczej;

- „Europejski program walki z ubóstwem” - projekt na rzecz zapewnienia spójności społecznej i terytorialnej, tak aby korzyści płynące ze wzrostu gospodarczego i zatrudnienia były szeroko dostępne, a osoby ubogie i wykluczone społecznie mogły żyć godnie i aktywnie uczestniczyć w życiu społeczeństwa [Dokument elektroniczny, tryb dostępu: http://eurlex.europa.eu/ LexUriServ/LexUriServ.do?uri=COM:2010:2020:FIN:PL:PDF, data wejścia: 20.06.2014].

W realizację siedmiu powyższych projektów przewodnich będzie zaangażowana Unia Europejska i państwa członkowskie Unii, jak również będa konieczne skoordynowane działania wszystkich partnerów społecznych i obywateli Unii. Istotę takich działań podsumował w słowie wstępnym Jose Manuel Barroso: warunkiem naszego powodzenia jest petne zaangażowanie europejskich prazywódcón i instytucji. Do realizacji nowej strategii potržebne sa skoordynowane driatania w całej Europie, obejmujace również partnerón spotecrnych i przedstawicieli spoleczeństwa obywatelskiego. Tylloo driekei wspótpracy Unia może przez-

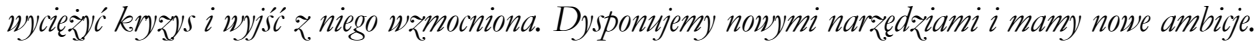
Nadszedt czas, by je wspólnie urzecsyynistnić [Dokument elektroniczny, tryb dostępu: http://eurlex.europa.eu/LexUriServ/LexUriServ.do?uri=COM:2010:2020:FIN:PL:PDF, data wejścia: 20.06.2014].

Rdzeniem strategii „Europa 2020” i instytucją całkowicie zaangażowaną w jej realizację będzie Rada Europejska oraz Komisja Europejska. Obie instytucje wskazuja, że w celu osiagnięcia zaplanowanych wyników, Unia Europejska będzie potrzebować silniejszego modelu zarządzania gospodarczego. Stąd zobowiązano państwa członkowskie Unii do opracowania i przekazania do Komisji Europejskiej krajowych programów reform na rzecz realizacji strategii „Europa 2020”. 
Zadaniem tych krajowych programów jest budowa trwałych podstaw wzrostu gospodarczego, łącząc cele unijne z priorytetami krajowymi. Przedstawione w nich reformy, ukierunkowane na wzrost inteligentny, zrównoważony i sprzyjający włączeniu społecznemu, mają umożliwić przezwyciężenie zidentyfikowanych barier wzrostu hamujących potencjał rozwojowy państw członkowskich Unii Europejskiej, jednocześnie przyczyniając się do wzmocnienia pozycji Unii Europejskiej na arenie międzynarodowej.

Strategia „Europa 2020”, która została przyjęta przez Radę Europejską 17 czerwca 2010 roku, to kluczowy dokument dla średniookresowej strategii rozwoju kraju w kontekście członkostwa Polski w Unii Europejskiej. Należy wskazać, że krajowy system dokumentów strategicznych został określony w Ustawie z.06.12.2006 roku o zasadach prowadzenia polityki rozwoju (Dz. U. 2009 r., Nr 84, poz. 712 ze zm.). Ustawa ta m.in.: definiuje średniookresową strategię rozwoju kraju, w tym horyzont czasowy jej obowiązywania, określa jej rolę oraz relacje z innymi dokumentami, ustala wewnętrzną strukturę. Ustanawia również wymóg okresowej aktualizacji strategii - co najmniej raz na cztery lata [Ustawa ₹ dnia 06.12.2006..., 2009].

Wykonując postanowienia Rady Europejskiej w odniesieniu do strategii „Europa 2020”, Rada Ministrów Rzeczypospolitej Polskiej uchwałą nr 157 z 25 września 2012 roku postanowiła przyjąć „Strategię Rozwoju Kraju 2020” (ŚSKR), [Uchwała nr 157 Rady Ministrów..., 2012]. Jest ona elementem nowego systemu zarządzania rozwojem kraju.

W nowym systemie do głównych dokumentów strategicznych, na podstawie których jest prowadzona polityka rozwoju, należą: długookresowa strategia rozwoju kraju DSRK („Polska 2030. Trzecia fala nowoczesności”) określająca zasadnicze trendy, wyzwania oraz koncepcję rozwoju kraju w perspektywie długookresowej, średniookresowa strategia rozwoju kraju - ŚSRK („Strategia Rozwoju Kraju 2020”) - najważniejszy dokument w perspektywie średniookresowej wyznaczający cele strategiczne rozwoju kraju do 2020 roku, kluczowy dla ustalenia działań rozwojowych, w tym możliwych do sfinansowania w ramach przyszłej perspektywy finansowej Unii Europejskiej na lata 2014-2020, a także dziewięć zintegrowanych strategii służących realizacji założonych celów rozwojowych.

W zatwierdzonym załączniku do uchwały nr 157 Rady Ministrów z 25 września 2012 roku pod tytułem Zało:̇enia realizacji programu operacyjnego Inteligentny Rožwój 20142020 zwrócono uwage, że główna strategia rozwoju w średnim okresie, uwzględniając zasadnicze wyzwania zawarte w DSRK, wskazuje strategiczne zadania państwa, których podjęcie w perspektywie najbliższych lat jest konieczne, by wzmocnić procesy rozwojowe wraz z szacunkowymi wielkościami niezbędnych środków finansowych. W tej nowej „Strategii Rozwoju Kraju 2020” istotnym i nowym elementem jest Wieloletni Plan Finansowy Państwa, przygotowywany na podstawie przepisów Ustany z dnia 27 sierpnia 2009 roku o finansach publicznych (Dz. U. Nr 157, poz. 1240 ze zm.). Zawiera on prognozę środków przeznaczanych z budżetu państwa na realizację strategicznych celów rozwojowych w perspektywie czteroletniej [Ustawa z dnia 27.08. 2009 roku..., 2009].

Cele przyjętej „Strategii Rozwoju Kraju 2020” w dużym stopniu wpisują się w realizację projektów zawartych w strategii „Europa 2020”. 
Należą do nich w szczególności następujące cele:

- wzrost wydajności gospodarki - projekt przewodni - „Polityka przemysłowa w dobie globalizacji”;

- zwiększenie innowacyjności gospodarki - projekt przewodni - „Unia innowacji”;

- $\quad$ rozwój kapitału ludzkiego - projekt przewodni - „Mobilna młodzież”; projekt przewodni - „Program na rzecz nowych umiejętności i zatrudnienia”;

- zwiększenie wykorzystania technologii cyfrowych - projekt przewodni „Europejska agenda cyfrowa”;

- bezpieczeństwo energetyczne i środowiskowe - projekt przewodni - „Europa efektywnie korzystająca z zasobów";

- zwiększenie efektywności transportu - projekt przewodni - „Europa efektywnie korzystająca z zasobów".

Realizacja tych celów będzie przebiegała między innymi w rytmie Europejskiego Semestru, który stanowi obecnie podstawowy instrument koordynacji polityki gospodarczej Unii Europejskiej.

Polska, mimo podejmowanych wysiłków w celu budowy gospodarki opartej na wiedzy, wciąż nie jest zaliczana do grona innowacyjnych państw oferujących wysoko zaawansowane produkty i usługi.

W Unijnym Rankingu Innowacyjności (IUS) za 2012 rok Polska zajmowała czwarte miejsce od końca i została zaklasyfikowana do grupy państw określonych jako „skromni innowatorzy", przy czym dystans dzielący Polskę od europejskich liderów innowacji oraz od średniej unijnej jest nadal znaczny. Postęp w omawianej sferze jest niezbędny do tworzenia nowych, opartych na wiedzy przewag konkurencyjnych i wymaga uruchomienia potencjału innowacyjnego polskiego społeczeństwa i krajowej gospodarki. Prognozy dla Polski w IUS za 2014 rok są jeszcze gorsze. W 2014 roku Polska zajęła 25. miejsce wśród 28 ocenionych krajów Unii Europejskiej.

Zgodnie z Założeniami Umowy Partnerstwa przyjętymi przez Radę Ministrów 15 stycznia 2013 roku jest planowana realizacja krajowego programu operacyjnego dotyczącego: innowacyjności, badań naukowych i ich powiązań ze sferą przedsiębiorstw. Jego robocza nazwa to Program Operacyjny Inteligentny Rozwój.

\section{Podsumowanie}

Przedmiotem niniejszej pracy jest ukazanie i analiza procesów rozwoju na podstawie Programu Operacyjnego Inteligentny Rozwój. Czynnikami sprawczymi procesów rozwojowych są w szczególności: wiedza, innowacyjność, inwestycje i finanse. Spośród tych czynników wiedza ma kluczowe znaczenie i to ona narzuca każdemu człowiekowi takie działanie i takie zachowanie, które dla rozwoju ludzkości są określane mianem inteligentnego cywilizacyjnego rozwoju.

Z tego też względu najważniejszym czynnikiem stymulującym rozwój każdego kraju czy też konkretnych przedsiębiorstw jest kapitał ludzki. To od inwencji twórczej i zdolności każdego pracownika zależy to, w jaki sposób będzie funkcjonować jego 
przedsiębiorstwo, a w szerszej perspektywie jego ojczyzna. Właściwe zarządzanie zasobami ludzkimi, skoncentrowane na rozwoju potencjału każdego człowieka, jest zasadniczym czynnikiem trwałości i rozwoju w skali mikroekonomicznej jego zakładu pracy, a w skali makroekonomicznej regionu i państwa.

Każde państwo powinno dbać o intelektualny rozwój społeczeństwa. Jest to aktualna strategia działalności państwa i w Unii Europejskiej, natomiast w Polsce zyskała miano Programu Operacyjnego Inteligentny Rozwój.

Z tą strategią wiąże się wysoka ranga problematyki doskonalenia umiejętności zarządzania zasobami ludzkimi przez przedstawicieli społeczeństwa obywatelskiego i partnerów społecznych jako ważnego elementu funkcji personalnej w kraju czy regionie. Należy zaznaczyć, że nawet najlepiej opracowana strategia rozwoju nie zostanie wdrożona bez aktywnego zaangażowania i wsparcia całego społeczeństwa.

W artykule podkreślono, że Polska znajduje się w wyjątkowym okresie gospodarczej historii świata. Najbliższe lata i dekady na nowo określa gospodarczą mape świata, na którą będą oddziaływać: trendy demograficzne, migracje, innowacyjne technologie oraz rosnąca globalizacja procesów produkcji i usług na globalnym rynku pracy dążącym do równowagi.

W tym układzie światowym: wiedza, umiejętności, zdolności i doświadczenie społeczeństw oraz każdego obywatela z osobna mają coraz większe znaczenie jako czynnik konkurencyjności we wszelkiej dziedzinie działalności gospodarczej.

W pracy wskazano, odnosząc się do: wiedzy, innowacyjności i zasad prowadzenia polityki rozwoju, że przyszłość i rozwój gospodarczy każdego państwa i regionów będzie zależeć w dużej mierze od wiedzy społeczeństw i ich obywateli, jak również ich inwencji twórczej i wydajności w każdej dziedzinie pracy.

Każde państwo i każda instytucja w tym państwie powinny z posiadanej, rozwijanej i zdobywanej wiedzy czynić dobry użytek i zarządzać nią w taki sposób, aby wszystkie potrzeby społeczeństwa były należycie zaspokajane w celu jego optymalnego rozwoju i godnego życia.

\section{Literatura}

Bożyk P., Misala J., Puławski M. 2002 Miedzynarodowe Stosunki Ekonomiczne, Polskie Wydawnictwo Ekonomiczne, Warszawa.

Czaja S. 2009 Informacja jako podstawa ksztaltowania zrónnoważonego roz̧woju i gospodarki opartej na wiedšy, [w:] Zrównoważony rozwó́j gospodarki opartej na wiedzy, B. Poskrobko (red.), Wydawnictwo Wyższej Szkoły Ekonomicznej, Białystok.

Dokument elektroniczny, tryb dostępu: [http://ec.europa.eu/europe2020/europe-2020in-a-nutshell/priorities/smart-growth/index_pl.htm, data wejścia: 20.06.2014].

Dokument elektroniczny, tryb dostępu: [http://eurlex.europa.eu/LexUriServ/LexUri Serv.do?uri=COM:2010:2020:FIN:PL:PDF, data wejścia: 20.06.2014].

Dokument elektroniczny, tryb dostępu: [http://www.mg.gov.pl/Bezpieczenstwo + gospodarcze/Strategia+Europa+2020, data wejścia: 20.06.2014]. 
Duszyński P. 2007 Nowa ustawa o prowadzeniu polityki rožoju, „Serwis administracyjno-samorządowy", nr 3 (134).

Powichrowska B. 2011 Ksz̨altowanie wiedšy w przedsiebiorstwie, [w:] Pržedsiebiorstwo w warunkach arónnoważonej gospodarki opartej na wiedsy, B. Powichrowska (red.), Wydawnictwo Wyższej Szkoły Ekonomicznej, Białystok.

Rymarczyk J. 2010 Miedzynarodowe stosunki gospodarcze, Polskie Wydawnictwo Ekonomiczne, Warszawa.

Rynarzewski T. 2005 Strategiczna polityka handlu miedzynarodowego, Polskie Wydawnictwo Ekonomiczne, Warszawa.

Strategia Rozроји Kraju 2007-2015 2006, Ministerstwo Rozwoju Regionalnego, Warszawa.

Uchwała nr 157 Rady Ministrów z dnia 25.09.2012 roku w sprawie prayjecia Strategii Rozwoju Kraju 2020 (Monitor Polski z dnia 22.11.2012 roku, poz. 882).

Ustawa z. dnia 06.12.2006 roku o zasadach prowadzenia polityki rožwoju (Dz. U. 2009, Nr 84, poz.712 z późn. zm.).

Ustawa z. dnia 27.08. 2009 roku o finansach publicznych (Dz. U. 2009, Nr 157, poz. 1240 z późn. zm.).

Waldziński D. 2009 Kryzys gospodarcyy kryaysem kultury, [w:] Od wielkiego kryyysu gospodarczego do wielkiego kryayssu finansowego. Perturbacje w gospodarce swriatowej w latach 1929-2009, J. Kaliński, M. Zalesko (red.), Wydawnictwo Uniwersytetu w Białymstoku, Białystok. 